\title{
Contemporary Models of Organization of Power and the Macedonian Model of Organization of Power
}

\author{
Driton Kuçi, Assist. Prof. \\ Faculty of Law, State University of Tetova \\ driton.kuci@unite.edu.mk
}

\begin{abstract}
This paper is a critical analysis of the model of organization of power, which intends to prove that the traditional dichotomy parliamentary - presidential system has a relative methodological value in view of the character of the contemporary organization of power models. The Macedonian organization of power model is no exception to this statement. The political system is not determined only by the constitutional framework. It is also determined by the (un)democratic tradition, the model of political culture, the electoral and party system. In this sense, the same normative model works differently in different countries or different periods of development of the same political system. This is especially evident in the relations between Parliament and Government. The dominance of the executive government is not characteristic only of the organization of power model in the Republic of Macedonia, it is a global tendency as well. In that sense, the Assembly of the Republic of Macedonia shares the "fate" of the representative bodies in the contemporary parliamentary system. However, in the absence of a democratic tradition, the presence of subject political culture, strong elements of partocracy and party state, fragile and fragmented civil society and weak general public, the dominance of the executive over the legislative government acquires dramatic dimensions.
\end{abstract}

Keywords: organization of power; legislative power; executive power; political control

\section{Introduction}

The separation of powers as a fundamental principle of the organization of state government has a long tradition and is an essential element of the philosophy of important political thinkers in search of ways and instruments to limit the absolute monarchical power. The idea behind the separation of powers is the guiding idea in overcoming absolute monarchy. This line of thought was supported by Thomas Hobbes, John Locke and Charles Montesquieu. Montesquieu, raised the question of separation of powers in book XI, Chapter 6, "On the spirit of laws"1 in describing the English Constitution, although he did not specifically mention the phrase "separation of powers". It seems that the basic premise summarizing the theory of Montesquieu on the separation of powers is as follows: "To prevent the abuse if power, it is necessary from the very nature of things that power should be a check to power." Montesquieu advocated separation of the legislative (puissance legislative), the executive (puissance executrice) and the judiciary (puissance de judger). ${ }^{2}$

The doctrine of Montesquieu on the separation of powers was brought to life in the U.S. Constitution, dated 1787, which inaugurated a presidential system of organization of power. "The intent was to remove the misunderstandings occurring at that time; it was to save the people from autocracy, by applying the principle of separation of powers." ${ }^{3}$ Although the Constitution of the United States does not contain an explicit affirmation of the principle of separation of powers and government, it is nevertheless obvious, as the first, second and third article refer to the legislative, executive and judicial power. The legislative power belongs to Congress ${ }^{4}$, the executive to the President ${ }^{5}$, and the judicial power is exercised by the courts or, i.e. the judicial power of the United States has been entrusted with the Supreme Court. 6 "Every American

\footnotetext{
${ }^{1}$ Charles- Louis de Secondat (Montesquieu), De l'esprit des lois,Paris, as found in R.Malnes, K.Midgard, Политичка фрилозофрија, Скопје, 2008, pg.307

2 R.Lukic, Monteskjeova politička teorija, Arhiv za pravne i drustvene nauke, Beograd, 1995, pg.119-134

3 TH.O. Sargentich, "The limits of the Parliamentary Critique of the Separation of Powers", 34 Wm. \& Mary L,. Rev.679, (1993)

${ }^{4}$ Article 1 ,Section 1 of the U.S. Constitution

${ }^{5}$ Article 2,Section 1 of the U.S. Constitution

${ }^{6}$ Article 3 ,Section 1 of the U.S. Constitution 
knows that power in America is divided into three segments ... The function of Congress is to make laws, the President, to execute the laws, and the Court, to interpret the laws."1

When we say that the system is based on the principle of separation of powers, this means that the relations between the holders of state power are characterized by organizational and functional independence. In this respect, we refer to systems based on the principle of strict separation of powers (presidential system) and systems based on flexible separation of powers (parliamentary and mixed systems). It is notable that all forms of organization of state power occurred and developed empirically. ${ }^{2}$ The parliamentary system originated in England, and the presidential system in the U.S. In fact, political science, builds the model of the parliamentary system based on the English political experience, and the presidential system based on the American model.

\section{Important features of the parliamentary system}

The parliamentary system of government is based on the principle of flexible separation of powers. Unlike the parliamentary system, the presidential system is based on the principle of strict separation of powers. ${ }^{3}$

In the parliamentary system there is a balance of the three powers, and mutual relations are regulated by mechanisms of cooperation of the legislative and executive authorities. ${ }^{4}$ Apart from the flexible separation of powers, an important characteristic of parliamentary systems is the interdependence, i.e. the political responsibility of the Government to the Parliament, where the Parliament has the power to vote no confidence to the Government and the Government can ask the Head of State to dismiss Parliament. Furthermore, the ministerial and parliamentary functions are compatible, because members of the cabinet (the Government) must be members of Parliament, as is the case in England, but not in the Netherlands ${ }^{5}$ Norway $^{6}$ and Luxembourg ${ }^{7}$.

The birthplace of the pure/classical parliamentary system is England (Mater Parliamentorum). ${ }^{8}$ Although Great Britain has a constitution in the material sense, it is a specific example in its modern constitutionalism, in the absence of written, i.e. codified constitution. This legal and political paradox springs from and responds to a unique historical tradition in which the fight against absolute power, in support of limited power, and the recognition of the Parliament, as the carrier of the sovereignty and a school of democracy, along with the rule of law and the changing constitution discarded the need for a written Constitution. ${ }^{9}$ In Great Britain, the contemporary model of government organization qualifies as a cabinet system or a system of cabinet government, even as a prime minister system, because of the dominant role of the cabinet, or the prime minister. In England, the House of Commons (lower house) selects the Cabinet and the Cabinet is accountable to the House of Commons, however the Cabinet can also dismiss the House of Commons in case of a no-confidence vote against them, according to the maxim stand or fall together. As for the responsibility of the Cabinet to the Parliament, the rare occurrence of a no-confidence vote does not diminish its importance.

In this country, the parliamentary system actually arose from and in relation to the political responsibility of the government and its two essential elements; first: the government is fully accountable for its work, i.e. the entire cabinet must enjoy the confidence of the House of Commons, and second, in case of no-confidence, the government resigns ${ }^{10}$. However, there are still cases where the Prime Minister was overthrown by the House of Commons, the one with MacDonald in June 1924 and the one with Callaghan in March $1979^{11}$.

\footnotetext{
1 The Federalist, 1961, No.48. pg. 347

Constitutional Law, Edward Elgar Publishing, Cheltenham, 2011, pg.234.

${ }^{4}$ С.Шкариќ, Г.Силјановска, Уставно право, Скопје, 2009, pg.508.

${ }^{5}$ Article 57 , line 2 of the Constitution of the Kingdom of the Netherlands.

${ }^{6}$ Article 62 of the Constitution of the Kingdom of Norway

${ }^{7}$ Article 60 of the Constitution of Luxembourg

${ }^{8}$ С.Шкариќ, Г.Силјановска, Уставно право, Скопје, 2009, pg.512.

9 In this respect see also О. Диамел, Уставно право-Демократиuте, Скопје, 2004, pg.108

${ }^{10}$ С.Шкариќ, Г.Силјановска, Уставно право, Скопје, 2009, pg.512.

11 О. Диамел, Уставно право- Демократиите, Скопје, 2004, pg.117.
}

2 С. Климовски, В. Митков, Т. Каракамишева и Р. Тренеска, Уставно право, Просветно дело, АД. Скопје, 2003, pg.350

${ }^{3}$ R.J Krotoszynski, " The separation of legislative and executive powers" , in Tom Ginsburg, Rosalind Dixon (eds) , Comparative 
With respect to the relationship between the legislative and executive power, it must be noted that, in England, although the legislative function is formally in the hands of parliament, in over $90 \%$ of cases, the Cabinet proposes the laws. The situation is similar in other modern democracies, with the exception of the U.S., where Congress has still retained a proactive role in the legislative process, and only the members of the House of Representatives and the Senate are authorized to propose and adopt laws. Nevertheless, the aforementioned statement with respect to the British parliamentary reality does not mean that British MPs have given up proposing legislation. It only means that in today's environment, the control function towards the Cabinet has become the dominant feature of the House of Commons. The budgetary function and control, has also been reduced to the close supervision of the executive branch policy, particularly with the departmental select commissions, introduced in 1979.

Throughout history and even today, the parliamentary system is found in various forms in Italy, Belgium, the Netherlands, Sweden, Norway, Japan, India, Canada and other countries. ${ }^{1}$ After World War II, the Constitution of Italy introduced features of a classic parliamentarism. The organization of power is based on the principle of separation of powers. ${ }^{2}$ The characteristic of the Italian parliamentarism is the responsibility of the Government before the two houses, unlike other countries with a parliamentary system in which the Government answers only to the House of Commons (lower house). The Parliament can delegate the legislative function to the Government, but only with prior, set out principles and guidelines by the Parliament, and only for a limited time and in certain areas. ${ }^{3}$

\section{Presidential model of government organization}

The presidential system is based on the principle of strict separation of powers into legislative, executive and judicial, as well as the system of checks and balances. This system ensures the independence of the three branches of government. The name of this system comes from the shape of the executive power, which is performed by a collegiate body - the President. The function of the head of state and head of government are united in one person - the President. ${ }^{4}$

Therefore, the flexibility of the executive functions in the collegiate body is the key feature of the presidential system. ${ }^{5}$ Apart from that, the presidential system is characterized with: relations between the legislative, executive, and judicial powers, structured on the principle of checks and balances. In a presidential system, there is a greater degree of independence of each of the three powers, in comparison to the parliamentary system. ${ }^{6}$

There is no clear constitutional model of the presidential system in the modern democracies, except in the United States. ${ }^{7}$ The U.S. Constitution introduces not only a model of presidential republic; it also introduces a model of a presidential system of organization of state power. More than two hundred years after the adoption of the U.S. Constitution of 1787, the U.S. presidential republic and the American presidential model of government organization still function efficiently with the help of the checks and balances among the three powers. ${ }^{8}$

The aim of the founding fathers of the American constitution was to create a government organization which will provide the right balance between the legislative, executive and judicial power. However, the relationship between the legislative and the executive power is not always determined solely and exclusively by the constitutional framework. In certain situations, the President can interfere in the legislative activity, which is the responsibility of Congress. When talking about presidential powers it should be underlined that he/she possesses the de facto authorities, which are not provided for in the Constitution. Many presidents in the American constitutional history have adopted executive orders. This power of the President of the United States is also seen in the recent initiatives of the incumbent President Barack Obama. Namely, on

\footnotetext{
${ }^{1}$ On the British cabinet system, the French fragmentary parliamentarism of the III and IV French Republic and the German chancellor system see V. Vasovic, str. 336-405; 456-466 and 577-639.

2 Articles 55-137, of the Constitution of the Republic of Italy

${ }^{3}$ Article 76 of the Constitution of the Republic of Italy

${ }^{4}$ С. Климовски, В. Митков, Т. Каракамишева и Р. Тренеска, Уставно право, Просветно дело, АД. Скопје, 2003, pg.358

${ }^{5}$ С.Шкариќ, Г.Силјановска, Уставно право, Скопје, 2009, pg.503.

${ }^{6}$ Sokol-Smerdel, "Organizacija vlasti", Narodne novine, Zagreb, 1988, str.115.

7 B.Guy Peters, The Separation of Powers in Parliamentary Systems, Chapter III, p. 68, in Presidential Institutions and Democratic Politics-Comparing Regional and National contexts, edited by Kurt Von Menheten, London, 1997.

8 Г. Силјановска-Давкова," Современи "модели" на организација на власта: дилеми и предизвици", Zbornik pravnog fakulteta u Zagrebu br.2, 2011, pg. 365-391
} 
issues that he cannot push through Congress, he invokes the executive orders, which, in turn stimulates debate on the constitutionality of these Presidential acts. ${ }^{1}$ In the case of international agreements, which fall under the authority of the President, that should be in turn ratified by the Senate, before entering into force, the practice shows cases in which American presidents sign so-called executive agreements, bypassing international treaties that require ratification.

Different political systems recognize different types of veto: pocket veto, partial veto, package veto. ${ }^{2}$ The U.S. Constitution offers a pocket veto, which is often used. Namely, if Congress passed a legislative proposal and submitted this to the President for signing in the last ten working days before the end of session, the President can decide not to respond in any way, because from a formal aspect he is robbed of the possibility to state his position in the ten-day deadline which is provided for in the Constitution. By putting a pocket veto the president feels more comfortable, since it enables him to avoid explicitly explaining his reasons for not signing, the ordinary veto may create certain political problems. Basically, the consequences of pocket veto are that the specific legislative proposals must again go through the whole procedure of adoption, which in any case, creates difficulties for the proposal/bill to become a law. This demonstrates the importance and role of the President in such a system of separation of powers.

In the American political system, the President, as head of the biggest world power, de facto elected by the people, freely defines the composition of his "government" that the Congress cannot topple, and armed with the powers and means, he runs the country. ${ }^{3}$ Since he/she is elected on direct elections, the President is not accountable to Congress, i.e. has no political responsibility, and remains in his post until the expiry of the four-year term, regardless of his/her policies and regardless of whether Congress or the voters are satisfied or not with his work. Accordingly, the only sanction which the U.S. President is subject to is him not getting re-elected on the following elections. In the U.S., in addition to the President, the President's aides and associates, as well as the members of his cabinet have no responsibility before Congress. They are appointed and replaced depending on the will of the President. Therefore, the principle of separation of powers in this regard is very consistently applied: independent in relation to the legislative, the executive does not bear political responsibility before the legislative branch. ${ }^{4}$

The President can only answer to impeachment charges 5 . In such circumstances, the procedure for liability begins in the House of Representatives, where the impeachment charges are raised with a 2/3 majority vote. Then, it goes to the Senate, which, in this case, is not chaired by the Vice President of the United States, who usually chairs the Senate, but the Chief Justice. In 1868, the Senate was one vote away from impeaching former President Andrew Johnson. In August 1974, the U.S. President Richard Nixon resigned to avoid impeachment on the Watergate Affair. In January 1998, impeachment was also raised against President Bill Clinton, but it failed because the Senate did not provide two-thirds of the vote required for his impeachment.

\section{Mixed model of organization of power}

The combined or mixed system is a form of state government, which is a combination of principles and decisions taken from the parliamentary and presidential system. This system appears as a way out of the difficult dichotomy presidential parliamentary system. The theoretical literature devoted to this system is relatively poor. Sartori is one of the few proponents of the mixed system which gives an advantage over the extreme parliamentarism and the extreme presidentialism.

Robert Elgie distinguishes three kinds of definitions for determining its main features. The first is governed by the real power of political institutions. As a semi-presidential system, this type of definition gives the double-hated executive power to the president who has pronounced powers. ${ }^{6}$ In order to determine the existence of this system, it is sufficient to determine the greater power of the President in comparison to that of the prime ministers and cabinet. This definition, as a reflection

\footnotetext{
${ }^{1}$ Available in www.usnews.com/debate-club/is-obamas-immigration-executive-order-legal

2 Б. Ванковска, Политички систем, Скопје, 2007, pg.122.

${ }^{3}$ О. Диамел, Уставно право-Демократиuте, Скопје, 2004, pg.122.

${ }^{4}$ M. Jovicic, "Parlamentarni sistem nasuprot predsednickom i skupstinskom sistemu", Arhiv za pravne i drustvene nauke, 1992. Beograd, pg. 43-64.

5 The U.S. President can be impeached in cases of treason, bribery and other high crimes and misdemeanors.

6 Г. Силјановска-Давкова," Современи "модели" на организација на власта: дилеми и предизвици", Zbornik pravnog fakulteta u

Zagrebu no.2, 2011, pg. 369
} 
of the semi-presidential system refers to most countries from Central and Eastern Europe, including the countries that emerged from the Soviet Union.

The second type of definition, combines constitutional decisions to the current power of the holders of executive power. According to Maurice Duverger, the first theorist who used the term mixed system, the semi-presidential political system is one in which the constitution contains the following elements: the President of the Republic is elected in direct elections based on the universal suffrage; he/she has greater powers; and opposite him/her, the President has the Prime Minister and the Ministers who have executive and administrative powers and can retain the position as long as they have the support of Parliament. ${ }^{1}$ According to this definition, the semi-presidential system refers only to France and Portugal.

The third approach focuses on the institutional model, regardless of the actual relationship. Accordingly, there is a mixed system where the directly elected president, with a fixed term, exists side by side with the Prime Minister and Cabinet, which are accountable to Parliament for their work. ${ }^{2}$

The French Constitution of 1958 contains a model of a combined system. In this document, the most dominant and key figure in the constitutional system is the President of the Republic.

The President of the Republic appoints the Prime Minister. When the Government of the Prime Minister resigns, the President of the Republic dismisses him/her from office ${ }^{3}$, adopts laws, opens and closes sessions of the French Parliament by decree. The French model of state power also has characteristics of a parliamentary system: the political responsibility of the Government to the Parliament; the legislative initiative of the Government; the great influence of the Government in drawing up the agenda of the parliamentary sessions.

Although previously, the combined system was defined as a way out of the dichotomy of the presidential - parliamentary system, this model itself is somewhat contradictory and confrontational, especially when the President and the parliamentary majority are not from the same political camp. The result of this relationship is an increase in the risks of possible conflicts and freezes of the institutions.

\section{Macedonian model of organization of power}

The European political space is a world of hybrid models of organization of power. ${ }^{4}$ The Macedonian model of organization of state power belongs to the group of combined systems. Although it is dominated by elements of the parliamentary system, it has elements of the presidential system as well.

The parliamentary characteristics of the Macedonian model of organization of power are: the double-hated executive power; Government derives from the parliamentary majority, and is accountable to the Assembly; the Government is an (un)stable element of the executive power. However, some standard elements of a parliamentary system are lacking, such as: the compatibility of the MP and the ministerial position ${ }^{5}$; there is no possibility for dissolution of the Assembly by the President, at the request of the Government.

The elements of the presidential system can be identified in: the direct election of the head of state; the right of suspension veto; the responsibility of the head of state for violating the Constitution and laws (impeachment). Therefore, it is clear that this is neither a "clean" parliamentary nor a presidential system. This is a combined model of governance, in which there are relicts of the parliamentary system, or, as Professor Gordana Siljanovska refers to it, "Macedonian constitutional cocktail of the organization of power". 6

\footnotetext{
1 M. Duverger, "A new Political System Model: Semi-Presidential Goverment”, European Journal of Politicial Research, 1980, no.8, pg. 166, as found in Б. Ванковска, Политичли систем, Скопје, 2007, pg.144.

2 E. Robert( ed. ), Semi-Presidentialism in Europe, Oxford: Oxford University Press, 1999, p.146.

${ }^{3}$ Article 8 of the Constitution of the Republic of France

4 Г.Силјановска, "За македонскиот модел на организација на власта" , во Реформата на институциите и нејзиното значење за развојот на Република Македонија , Скопје, pg. 371.

${ }_{5}$ Similar in the French model, institute vigorously support by De Gaulle

6 Г. Силјановска, За македонскиот модел на организација на власта, во Реформата на институциите и нејзиното значење за развојот на Република Македонија , Скопје, pg. 347.
} 
Academician Evgeni Dimitrov ${ }^{1}$ has an original view of the organization of state power in the Republic of Macedonia. He believes that the Macedonian model of organization of power has combined the parliamentary model with certain elements of the assembly system. "Regardless of whether this will be a temporary or a lasting phenomenon, in addition to the existing basic forms of organization of the state, the current theory of constitutional law and political systems should define another new model, which could be labeled as a parliamentary system with elements of the assembly system. A system to which the Macedonian model of organization of state power would most certainly belong. ${ }^{2}$

\section{The impact of Government (executive) on the Assembly (legislative)}

The legislative and executive powers are two wheels of the same machine, if their movements are not harmonized, the machine will not function properly. ${ }^{3}$ The relationship between the legislative and executive authorities is not one-sided, on one hand, the legislature affects the executive, and on the other, the executive has tools to influence legislative. To assess the impact of the legislative power over the executive, the following issues are important: first, the method of determining the holder of executive power, second, the political control over the work of the executive power, i.e. the political accountability of the executive power and third, the change of the holders of the executive power. ${ }^{4}$

The general tendency in the parliamentary system is also present in the Republic of Macedonia, i.e. the imbalance in the separation of powers in favor of the Government, which becomes much more than the executive power. The Government of the Republic of Macedonia is deeply involved in the legislative authority through: the actual status of dominant proponent of the laws; proponent of the budget and other regulations; stating their opinion on the proposed laws and other regulations proposed by other authorized bodies; participation in the work of the Assembly and its working bodies and the right to request convening a sessions of the Assembly. Here, it is worth noting that over 95 percent of the adopted laws have been proposed by the Government and passed by the MPs, as they have been proposed, sometimes even without any discussion, in the style of the subject political culture and party obedience.

By the adoption of the Rules of Procedure in 2008, the Government had the right as the proponent to submit amendments right until the end of the debate. The practice shows that the government often abused this right. Sometimes, at the last minute, it proposed amendments that actually changed the previous content of a certain provision of the proposed law. ${ }^{5}$

The so-called "aggressive" government policy that literally models the parliamentary (dis)satisfaction depending on their needs ${ }^{6}$ is constantly present in the current parliamentary life in the Republic of Macedonia.

\section{Conclusion}

Constitutional norms and guarantees have proven to be insufficient for the democratic political system based on the principle of separation of powers. The lack of a longer democratic tradition, the (un)democratic political culture, with strong elements of patriarchalism and servitude not only in the interparty relations, but also in the work of the Assembly and the Government, as well as in their inter-relations stimulates undemocratic tendencies and distortions in the political system of the Republic of Macedonia, which has inevitably led to lagging behind in the European integration processes.

\footnotetext{
${ }^{1}$ PhD Evgenij Dimitrov, the first professor of Constitutional Law in the Republic of Macedonia

2 Е. Димитров, “Специфичностите на Парламентаризмот во Република Македонија според Уставот од 1991”, во Пет години од Уставот на Република Македонија, Здружение за уставното право на Македонија, Скопје, 1998, pg.208

${ }^{3}$ Е.Жиро, Извршната власт во демократскиите на Европа и Америка, Париз, 1938,pg.19, преземено од М. Ристовска, Односи меѓу законодавната и извршната власт во Република Македонија, Пет години од Уставот на Република Македонија,

Здружение за Уставно право на Македонија, Скопје, 1998, pg.230

4 lbid, pg. 230

${ }^{5}$ С.Гушева, Законодавната дејност на Собранието на Република Македонија, Скопје, 2009.

6 Т. Каракамишева, "Основни забелешки за системите на организација на власта и за потребата од реформирање на политичките институции во Република Македонија” , во Реформата на институциите и нејзиното значење за развојот во Република Македонија , Скопје, 2009, pg. 393-405. 


\section{Bibliography}

[1] Ванковска Билјана, Политички систем, Скопје, 2007.

[2] Vučina Vasovič, Savremene Demokratije I, Beograd, 2006

[3] Ginsburg,Thomas and Rosalind Dixon(eds),Comparative Constitutional law, Cheltenham:Edward Elgar Publishing, 2011.

[4] Гушева Снежана, Политичката контрола над Владата на Република Македонија, Скопје, 2008

[5] Гушева Снежана, Законодавната дејност на Собранието на Република Македонија, Скопје, 2009

[6] Гушева Снежана, Политичката контрола на Собранието врз Владата на

[7] Република Македонија,(LLMwork), Правен факултет во Скопје.

[8] Jennings John, Parliament, Cambridge, 1957

[9] Jovicic Miodrag, Parlamentarni system nasuprot predsednickom i skupstinskom sistemu, Arhiv za pravne i drustvene nauke, 1992

[10] Каракамишева Тања, Основни забелешки за системите на организација на власта и за потребата од реформирање на политичките институции во Република Македонија, Реформата на институциите и нејзиното значење во Република Македонија, Скопје, 2009

[11] Китановски Лазар, Поделба на власта, Скопје, 1995

[12] Malnes Raino, Midgaaed Knut, Politisk tenkning, Oslo, 2007

[13] Ристовска Марика, Организација на власта во уставните системи, Скопје, 2014

[14] Ристовска Марика, Теорија за поделба на власта и нејзината примена во уставниот поредок на Република Македонија (магистерски труд), Скопје, 1996

[15] Sargentich, Thomas, O. "The limits of the Parliamentary Critique of the Separation of Powers", $34 \mathrm{Wm}$. \& Mary L,. Rev, 1993.

[16] Силјановска Гордана, За македонскиот модел на организација на власта, МАНУ, Скопје, 2009

[17] Siljanovska-Davkova Gordana, Treneska Deskoska Renata, MAKEDONSKA (NE)DEMOKRATSKA SAGA: DAVID (SKUPŚTINA) PROTIV GOLIJATA (VLADA)? , u "Iskuśenja parlamentarizma" (ed) Slavisha Orlović), FPN i Fridrih Ebert, Beograd, 2013

[18] Siljanovska - Davkova, Gordana. "Parliamentarism and/or Presidentialism: Dilemmas and Challenges": www.juridicas.unam.mx/wccl/ponencias/14/266/pdf, Mexico City, World Congress of IACL, 2010

[19] Sokol Smerdel, Organizacija vlasti, Narodne novine, Zagreb, 1988.

[20] Тренеска Рената, Извршната власт во демократските системи, Матица македонска, Скопје, 1999

[21] Тренеска Рената, Типови на извршна власт (магистерски труд), Скопје, 1997

[22] Heywood Andrew, Politika, përkthyer nga Sonila Danaj, Botimi i dytë,Tiranë, 2002

Шкариќ Светомир, Силјановска-Давкова Гордана, Уставно право, Култура, Скопје, 2009 